\begin{tabular}{|c|l|}
\hline Title & $\begin{array}{l}\text { Screening level analysis for monitoring pesticide in river water using a hy drological diffuse poll lution model with } \\
\text { limited input data }\end{array}$ \\
\hline Author(s) & Matsui, Y.; Narita, K.; Inoue, T.; Matsushita, T. \\
\hline Citation & $\begin{array}{l}\text { Water Science \& Technology, 53(10), 173-181 } \\
\text { https://doi.org/10.2166/wst.2006.310 }\end{array}$ \\
\hline Issue Date & 2006 \\
\hline Doc URL & http://hdl.handle.net/2115/30271 \\
\hline Type & article \\
\hline File Information & WST 53-10.pdf \\
\hline
\end{tabular}

Instructions for use 


\section{Screening level analysis for monitoring pesticide in river water using a hydrological diffuse pollution model with limited input data}

\section{Y. Matsui ${ }^{\star}$, K. Narita ${ }^{\star \star}$, T. Inoue ${ }^{\star \star \star}$ and T. Matsushita**}

*Department of Environmental Engineering, Hokkaido University, Sapporo 060-8628, Japan, (E-mail: matsui@eng.hokudai.ac.jp)

**Department of Civil Engineering, Gifu University, Gifu 501-1193, Japan

***Toyohashi University of Technology, Toyohashi 441-8580, Japan

Abstract To predict rice-farming pesticide concentrations in river water with imprecise model inputs for screening-level analysis, a basin-scale runoff model was developed. The Monte Carlo method was applied to create estimates of input data regarding agricultural work schedules and parameters for pesticide decomposition and sorption in solids and water. The prediction accuracy of the model was evaluated when used with non-optimised pesticide parameters; the model was calibrated using hydrological data alone without reference to observed pesticide concentration data. Overall, predictions for the pesticide concentrations were successful within order-of-magnitude accuracy. The pesticide rankings according to the predicted concentration roughly agreed with those observed. The success of screening-level analysis indicates that the model prediction can help in selection of pesticides to be monitored and in determining the monitoring schedule for the river basin.

Keywords Modelling; pesticides; pollutograph; prediction; runoff; water quality

\section{Nomenclature}

$a_{\mathrm{W}, \mathrm{V}} \quad$ infiltration rate coefficients of the rice paddy field $(\mathrm{m} / \mathrm{s})$.

$a_{\mathrm{W}, \text { in }}, a_{\mathrm{W} \text {,out }}$ irrigation and drainage rate coefficients of the rice paddy field, respectively $\left(\mathrm{s}^{-1}\right)$

$a_{\mathrm{V}} \quad$ vertical flow rate coefficient $\left(\mathrm{s}^{-1}\right)$

$a_{\mathrm{H}} \quad$ lateral flow rate coefficient $(\mathrm{m} / \mathrm{s})$

A area of the compartment $\left(\mathrm{m}^{2}\right)$

$B \quad$ length on a side of a square grid (m)

$C_{1}$ and $C_{2}$ concentration in each compartment $\left(\mathrm{kg} / \mathrm{m}^{3}\right)$

$D \quad$ diffusion coefficient $\left(\mathrm{m}^{2} / \mathrm{s}\right)$

$L \quad$ distance between compartments (m)

$L_{\mathrm{R}} \quad$ river length in a compartment

$h \quad$ water level of the compartment (m)

$h_{0} \quad$ depth of the compartment (m)

$h_{\mathrm{W}} \quad$ water depth of the rice paddy field (m)

$h_{\mathrm{W}, 0} \quad$ objective water depth of the rice paddy field (m)

I slope (dimensionless)

$n_{\mathrm{M}} \quad$ Manning coefficient $\left(\mathrm{m}^{2 / 3} \mathrm{~s} / \mathrm{m}^{3}\right)$

$q_{\mathrm{D}} \quad$ solute diffusion rate between compartments $(\mathrm{kg} / \mathrm{s})$ 
$q_{\mathrm{W}} \quad$ flow rate of spill-over irrigation divided by the paddy area (rate of continuous irrigation in order to keep a certain water depth and to prevent hot water damage: extra amount of irrigated water spill over from the outlet of the paddy, $\mathrm{m} / \mathrm{s}$ )

$Q_{\mathrm{V}} \quad$ vertical flow rate $\left(\mathrm{m}^{3} / \mathrm{s}\right)$

$Q_{\mathrm{R}} \quad$ river flow rate $\left(\mathrm{m}^{3} / \mathrm{s}\right)$

$Q_{\mathrm{H}} \quad$ lateral flow rate $\left(\mathrm{m}^{3} / \mathrm{s}\right)$

$Q_{\mathrm{W}, \text { in }} \quad$ irrigation rate (flow rate of water to the paddy field, $\mathrm{m}^{3} / \mathrm{s}$ )

$Q_{\mathrm{W}, \text { out }} \quad$ drainage rate (flow rate of water from the paddy field, $\mathrm{m}^{3} / \mathrm{s}$ )

\section{Introduction}

A wide range of possible sources of diffuse pollution, including pesticides, have been found to originate on farms. In Japan, the fate of rice-farming pesticides and their concentrations in river water are particularly important issues for management of drinkingwater supplies, because (1) more stringent regulations have been promulgated for pesticide concentrations in drinking water and (2) rice-farming pesticides run off to river water at higher rates than do other pesticides used in upland fields. Rice-farming pesticides are dusted directly over the ponding water of paddy fields, and thus are more likely to contaminate river water by spill-over following rainfall or by water-ponding depth control, etc. Although the annual pesticide consumption for upland fields in Japan is no less than that for rice paddy fields, most of the pesticides detected in river water are those used in rice farming (Matsui et al., 2002). The prediction of pesticide concentrations in river water is of practical importance when used as a screening-level analysis, providing order-of-magnitude accuracy with minimal investment in time and resources in waterquality monitoring (Dabrowski et al., 2002). Screening-level analysis is important for selecting pesticides to be monitored and determining the monitoring schedule for river basins where different pesticides are applied from year to year.

While many models and their applications have been reported, few have been applied to rice-farming pesticides in runoff from rice-paddy fields (Inao and Kitamura, 1999; Li and Migita, 1992). Moreover, no attempt has been made to predict rice-farming pesticide concentrations in river water in a large catchment area that constitutes the local primary source of drinking water, probably owing to the difficultly of acquiring input data. Such data include the name of each pesticide product dusted, the quantity used, the dates of pesticide dusting, the varieties of rice planted, the dates of transplantation of rice seedlings, the time-variation patterns of water depth of rice-paddy ponding, parameter values of pesticide decomposition, and parameter values of pesticide sorption. Accordingly, the objective of this research is to predict rice-farming pesticide concentrations in river water with imprecise model inputs and no parameter optimization for a screening-level analysis.

\section{Model description}

Compartment model

A compartment model was used to describe the movement of pesticides in a river basin and to create pesticide pollutographs. In the model, a river basin was divided into a grid of $1 \mathrm{~km} \times 1 \mathrm{~km}$ grid cells. Each grid cell was subdivided into 12 compartments, including a river-water $(\mathrm{R})$ compartment, a river-bed (S) compartment, and paddy-field-soil (X and Y) compartments (Figure 1). Water and pesticides from all compartments except 


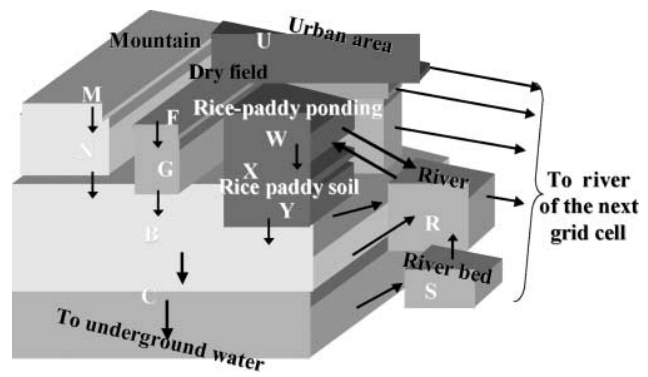

Figure 1 Compartment model in a grid cell and flow directions

the $\mathrm{C}$ compartment move laterally to the $\mathrm{R}$ compartment of one of the immediately surrounding eight grid cells, specifically, to the cell along the steepest downhill slope from the source cell. Lateral movement from the $\mathrm{C}$ compartment goes to the $\mathrm{R}$ compartment of the next grid cell via the $\mathrm{S}$ compartment of that grid cell. The irrigation water in the $\mathrm{W}$ compartment comes from the R compartment of the same grid cell. Vertical flows from all compartments except the $\mathrm{R}$ and $\mathrm{S}$ compartments are downward.

A set of differential mass-balance equations describing the dynamics of a solute (pesticide) and water in each compartment was formulated, based on the law of conservation of mass for the pesticide and the water. In the hydrology (water flow) part of the model, the rates of lateral water flow into and out of the $\mathrm{W}$ compartment $\left(Q_{\mathrm{W} \text {,in }}\right.$ and $Q_{\mathrm{W} \text {,out }}$, respectively) are described as functions of the water level $\left(h_{\mathrm{W}}\right)$ in the compartment:

$Q_{\mathrm{W}, \text { in }}=A a_{\mathrm{W}, \text { in }} \max \left(0, h_{\mathrm{W}, 0}-h_{\mathrm{W}}\right)+A q_{\mathrm{W}}$

$Q_{\mathrm{W}, \text { out }}=A a_{\mathrm{W}, \mathrm{out}} \max \left(0, h_{\mathrm{W}}-h_{\mathrm{W}, 0}\right)$

The water depth in the paddy field $\left(h_{\mathrm{W}}\right)$ is artificially controlled at various levels according to weather conditions and the growth stage of the rice. The desired water level in the rice paddy field $\left(h_{\mathrm{W}, 0}\right)$ and the spill-over irrigation flow rate $\left(q_{\mathrm{W}}\right)$ are input variables, which are determined by the rice farming schedules.

Vertical flow from the $\mathrm{W}$ compartment $\left(Q_{\mathrm{W}, \mathrm{V}}\right)$ is described as a function of water level in the rice paddy field; this water goes into the $\mathrm{X}$ compartment beneath the $\mathrm{W}$ compartment in the same grid cell:

$Q_{\mathrm{W}, \mathrm{V}}=a_{\mathrm{W}, \mathrm{V}} A\left(\frac{h_{\mathrm{W}}}{h_{\mathrm{W}, 0}}\right)$

The rates of lateral flow $\left(Q_{\mathrm{H}}\right)$ from the $\mathrm{M}, \mathrm{F}$, and $\mathrm{U}$ compartments are described by the Manning equation:

$Q_{\mathrm{H}}=\frac{A}{B} h \frac{1}{n_{\mathrm{M}}} h^{2 / 3} I^{1 / 2}$

The rates of lateral interflow from the $\mathrm{X}, \mathrm{Y}, \mathrm{N}, \mathrm{G}, \mathrm{B}$, and $\mathrm{C}$ compartments are described as a function of the water level in the compartment and the slope of the compartment:

$Q_{\mathrm{H}}=a_{\mathrm{H}} I\left(\frac{A}{B}\right) h$

Vertical flows from the X, Y, M, N, F, G, B, and C compartments are described as a function of percentages of each water content, which is equivalent to the water level 
relative to the compartment height:

$Q_{\mathrm{V}}=a_{\mathrm{V}} A\left(\frac{h}{h_{0}}\right)$

The Manning equation is also used to describe the flow rate in the R compartment:

$Q_{\mathrm{R}}=\frac{A}{L_{R}} h \frac{1}{n_{\mathrm{M}}} h^{2 / 3} I^{1 / 2}$

For solute movement between compartments, advection and diffusion are considered. Solute advection is given as the product of the concentration and water flow rate calculated from Eqs. 1-7. However, the maximum real concentration for each solute is limited by its solubility in water, so any amount of pesticide over the solubility limit must exist in the solid phase and is not subject to movement. The rate of solute movement by diffusion between compartments is given by the linear driving force model:

$q_{\mathrm{D}}=A \frac{D}{L}\left(C_{1}-C_{2}\right)$

Within a compartment, both the solute concentration and the water level are assumed to be uniform, each represented by a single variable. For example, rainfall is assumed to mix completely and uniformly with pesticides in the paddy-field-water (W) compartment. If a compartment consists of multiple subelements (soil-solid and soil-water), a dynamic equilibrium exists between the dissolved and sorbed fractions at all times; sorption processes are considered to be instantaneous and are described by a single constant (the solid-water partition coefficient) in the linear equilibrium relationship. Therefore, once the concentration in one phase is known, the concentration in the other phase can be calculated. Degradation of pesticides in each compartment follows first-order kinetics. The processes of pesticide uptake by plants and pesticide evaporation into the atmosphere were not considered in this model. The flow rate coefficient in each type of compartment (e.g. W, X) is assumed to be a single value (for each compartment) throughout the entire set of grid cells in the basin. These assumptions were made to reduce the total number of hydrologic parameters, even though the target river basin was divided into numerous grid cells, which prevented excessive uncertainty in determining the model parameter values.

\section{Site description and model application}

The Chikugo River basin $\left(1882 \mathrm{~km}^{2}\right.$; Figure 2) was selected to test the model and to predict rice-farming pesticide concentration. The Chikugo River basin includes rice-paddy fields $\left(261 \mathrm{~km}^{2}\right)$ cultivated by 22,860 farmers dusting with more than 100 kinds of pesticides. The Chikugo River basin was divided into 1882 grid cells. The catchment area comprised 22,584 compartments. A set of 45,168 equations was solved to describe the movements of water and a pesticide in the river basin. The model equations were solved as a system of ordinary differential equations by Gear's stiff method from the IMSL MATH/LIBRARY.

Application of the compartment model to the river basin required geographic data. The altitude of each compartment was determined from Geographic Information System (GIS) data (Geographical Survey Institute, 1999), and water flow directions between compartments were determined based on the direction of the steepest gradient. The GIS data (Geographical Survey Institute, 1990) were also used to calculate the areas of the compartments (e.g., paddy field, river, forest) in each grid. However, the GIS data available were old and may not reflect current land utilization. The area of the paddy fields, which 

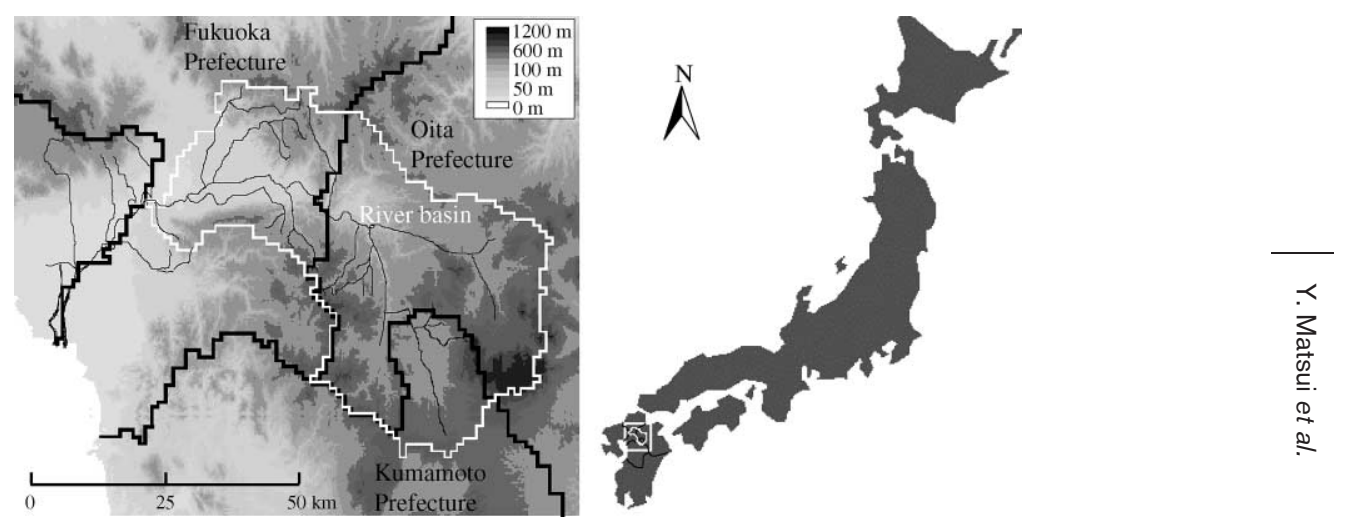

Figure 2 Location of Chikugo River and the target river basin

is the most important geographical information used in this study, was corrected with data published by the local governments (Census Statistics Office, 1997, 2002), which include data on the percentage of rice-paddy area removed from cultivation due to compulsory adjustments in production. The fallow paddy fields were regarded as upland field compartments.

\section{Model inputs}

Thirteen pesticides (Table 1 and Figure 3) were selected for verifying the model predictions, according to quantity consumed in the target river basin and detection in river water at high concentrations and frequency. Each pesticide is included as an active substance in several commercial pesticide products on the market. Pesticide dusting, irrigation, and drainage are the processes that most affect pesticide runoff among the numerous factors regarding agricultural work. Many factors (e.g., aerobic/anaerobic conditions, soil-sediment organic content) also affect pesticide decomposition and its partition between soil and water. Although some information has been reported and is available for these model inputs, the reported values for input parameters are subject to different kinds of uncertainties (Dubus et al., 2003). Therefore, a single reported value would not be appropriate to represent an input parameter in a whole area. It is more reasonable to assume that all rate parameter uncertainties are random. Model input data sets of

Table 1 Properties of each pesticide (British Crop Protection Council, 1994, 2003; U.S. Environmental Protection Agency, 2004)

\begin{tabular}{lllc}
\hline Pesticide & $\begin{array}{c}\text { Water solubility, } \\
\mathbf{~ m g / L}\end{array}$ & \multicolumn{1}{c}{$\begin{array}{c}\text { Soil sorption } \\
\text { coefficients, Koc (mL/g) }\end{array}$} & $\begin{array}{c}\text { Half-life in } \\
\text { soils (days) }\end{array}$ \\
\hline Daimuron & 1.2 at $20^{\circ} \mathrm{C}$ & 959,6855 & 50 \\
Mefenacet & 4 at $20^{\circ} \mathrm{C}$ & 3063 & $23-223$ \\
Thiobencarb & 30 at $20^{\circ} \mathrm{C}$ & 3170 & $14-21,180-240$ \\
Bromobutide & 3.54 at $25^{\circ} \mathrm{C}$ & 652,10430 & $31-64$ \\
Pyrazolate & 0.056 at $25^{\circ} \mathrm{C}$ & 7855,29830 & $8-10,10-20$ \\
Esprocarb & 4.9 at $20^{\circ} \mathrm{C}$ & 581,7952 & $30-70$ \\
Pretilachlor & 50 at $20^{\circ} \mathrm{C}$ & 254,1159 & 30 \\
Pyributicarb & 0.32 at $20^{\circ} \mathrm{C}$ & 1885 & $13-18$ \\
Bensulfuron- & 67 at $25^{\circ} \mathrm{C}$ & 370 & $88.5,28-140$ \\
Methyl & & & 7 \\
Cafenstrole & 2.5 at $20^{\circ} \mathrm{C}$ & 738,13950 & $7.083-0.42$ \\
Cyhalofop-butyl & 0.44 at $20^{\circ} \mathrm{C}$ & 1371,9280 & 28 \\
Pyrazosulfuron-ethyl & 9.76 at $20^{\circ} \mathrm{C}$ & 10,455 & 140 \\
Dimethametryn & 50 at $20^{\circ} \mathrm{C}$ & 254,1357 & 0.40 \\
\hline
\end{tabular}



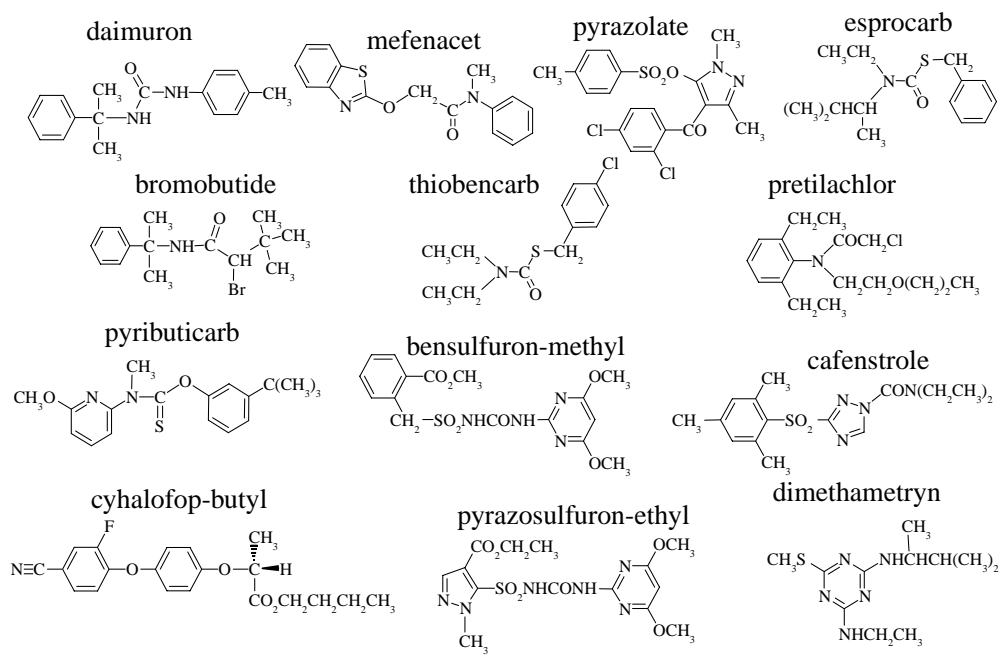

dimethametryn

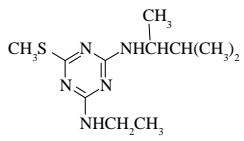

Figure 3 Molecular structures of pesticides

pesticide application dates, places (grid cells), quantities of pesticide applied, irrigation and drainage schedules, degradation rate, and solid-water sorption coefficients in each compartment were created by the Monte Carlo method using available and published data by a procedure described elsewhere (Matsui et al., 2005). A total of 2000 data sets for a pesticide, thiobencarb, were created, and a set of 2000 Monte Carlo simulations yielded a prediction of concentrations of the pesticide in river water (a prediction-of-pesticide pollutograph). For the other pesticides, the number of simulations for each pesticide was limited to 30 due to the time constraints imposed by the time that model calculation requires.

\section{Predicting pesticide concentrations}

\section{Comparison of time-series pesticide concentrations as observed and as predicted}

After the hydrological system parameters were calibrated, the hydrological and solute models were solved simultaneously by substituting the input data for the pesticide, giving the predicted concentrations of the pesticide in river water for the rice-cultivation seasons of 2000 and 2001. A total of 2000 data sets for thiobencarb were created, and a set of 2000 Monte Carlo simulations yielded a simulation predicting concentration of the pesticide in river water. Figure 4 shows the time variations in the predicted and observed thiobencarb concentrations for the Chikugo River basin in 2000 and 2001. Of the observed data points, $68 \%$ were in the range predicted with the 2000 data sets of the Monte Carlo inputs, and more than $40 \%$ were within the 1-99\% range of the prediction. Although the pesticide-dusting dates and the quantity applied are influential factors for predictive accu-
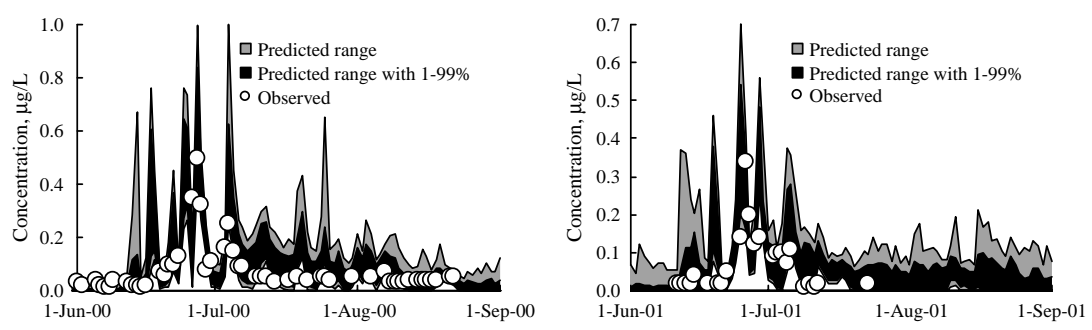

Figure 4 Predicted and observed thiobencarb concentrations in Chikugo River in 2000 and 2001 
racy, our prediction was not based on precise data for the quantities used and dates of pesticide dusting by individual farmers. Moreover, the model calculations were conducted without optimizing the pesticide decomposition or sorption parameters. In the light of these limitations, we consider the thiobencarb pollutograph to be reasonably successful for a first estimate.

\section{Comparison of June-July-averaged concentrations as observed and as predicted}

Figure 5 shows a comparison of predicted and observed concentrations of 13 pesticides for the June-July periods of 1999-2002, during which water sampling and pesticide concentration measurements were frequently conducted and pesticides were actually detected with high concentrations over the detection limits. Bars for concentrations indicate the arithmetic mean values of time-series concentrations predicted for June-July and of the arithmetic mean values of concentrations observed in June-July (the absence of a bar means the pesticide observation was not conducted for that year and for that pesticide). Water samples for pesticide concentration analysis were collected at 9 a.m., and the maximum number of the sampling events during the June-July periods was 43 times for two pesticides (mefenacet and bromobutide, both in June-July 2003). The concentration of one pesticide (dimethametryn) was measured just four times during June-July 1999. Some pesticides, such as pyrazolate, were not analysed at all. Therefore, the average values of observed pesticide concentrations may not necessarily represent the concentrations of the pesticides in the June-July period. On the other hand, the model calculation provides continuous outputs of time-varying concentrations and the predicted concentrations for the June-July periods are given as time-average values of the continuous outputs. Therefore, it may not be inappropriate to simply compare the observed values and the predicted values, in particular for pesticides for which the numbers of
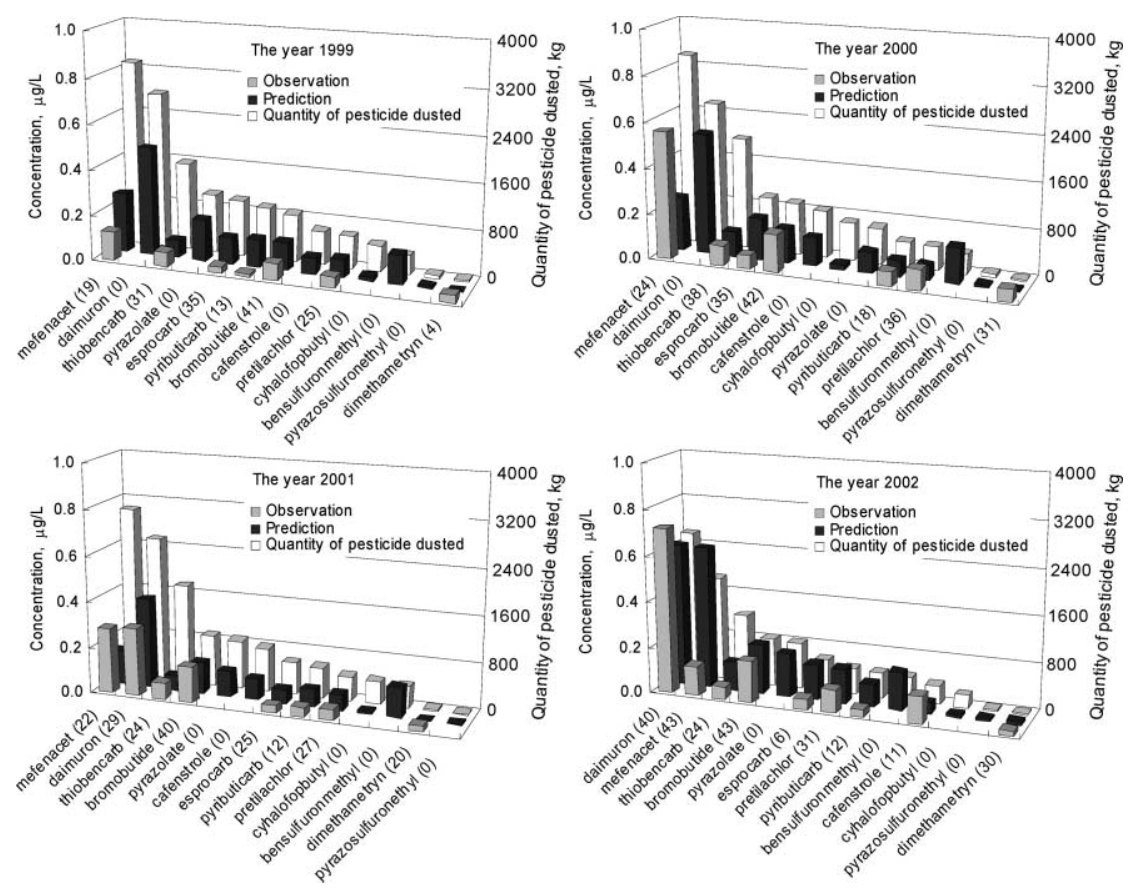

Figure 5 Comparison of June-July-averaged concentrations as observed and as predicted by the model (the numerical values in parentheses are the numbers of observations in June-July periods; the absence of a bar indicates no observed data) 


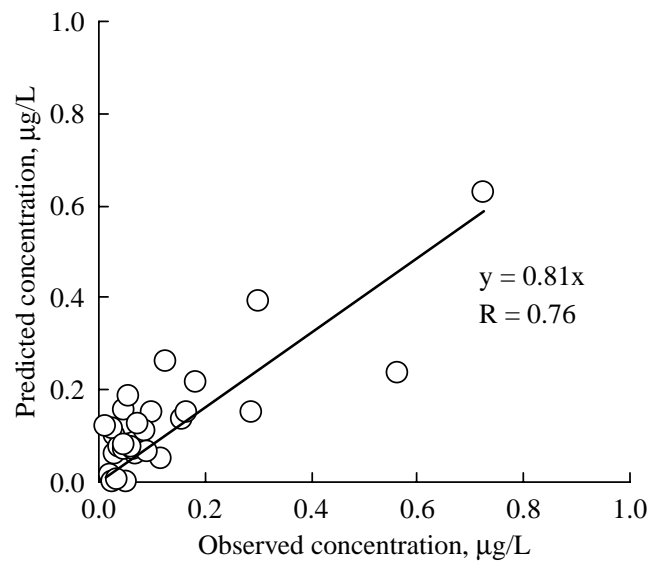

Figure 6 Comparison of observed and predicted pesticide concentrations (except mefenacet in June-July 2000)

sampling and observation were few. Nonetheless, the predicted concentrations were in fairly good agreement with the observed ones.

The figure also shows the quantity of each pesticide dusted in the target area in each year, which was estimated by the data of the annual sales of pesticide products obtained from the annual reports published by the Japan Plant Protection Association (2000, 2001, 2002, 2003). Pesticides that were dusted in large quantities did not necessarily lead to high concentrations in river water, as empirically known, and this empirical knowledge is validated by the model's prediction. Pesticide rankings by concentration, which could not be predicted solely by the quantity of pesticide dusted, are well predicted by the model.

For some pesticides, however, discrepancies still arise between observed and predicted concentrations, probably because the lack of available precise data leads to imprecise model input for quantities and dates of pesticide dusting, pesticide decomposition, and pesticide sorption. For example, prediction of a pesticide (mefenacet) far exceeded observation for the year 2002, although the model predictions for the years 1999-2001 were consistent with observations for those years. Further study is still needed to improve the prediction ability of the model. Excluding the data point for mefenacet in June-July 2002, the coefficient of correlation between predicted and observed concentration was $\mathrm{R}=0.76$ (see Figure 6).

A practical application of the model prediction is a screening-level analysis, in which pesticides to be monitored are selected and the monitoring schedule is determined for a catchment area where different pesticides are applied from year to year. The effectiveness of the screening-level analysis by the model prediction was examined for two pesticides, daimuron and cafenstrole. The predictions of 1999 and 2000 suggest daimuron concentrations to be 0.48 and $0.53 \mu \mathrm{g} / \mathrm{L}$, respectively, which are the highest pesticide concentrations predicted by the model for those years (Figure 5). However, measurement of daimuron concentrations did not start until 2001. Daimuron concentrations observed in 2001 and 2002 (0.3 and $0.7 \mu \mathrm{g} / \mathrm{L}$, respectively) were similar to the predicted values $(0.39$ and $0.63 \mu \mathrm{g} / \mathrm{L}$, respectively). For the other pesticide, cafenstrole, concentrations were not measured until 2002, while the predicted concentrations for 1999, 2000, and 2001 were $0.07,0.12$, and $0.09 \mu \mathrm{g} / \mathrm{L}$, respectively. The observed cafenstrole value for 2002 was $0.12 \mu \mathrm{g} / \mathrm{L}$, similar to the concentrations predicted for the previous years (the predicted concentration for 2002 was $0.05 \mu \mathrm{g} / \mathrm{L})$. 


\section{Conclusions}

A basin-scale runoff model was developed to predict rice-farming pesticide concentrations in river water with imprecise model inputs for screening-level analysis, which can be used for selecting pesticides to be monitored and determining the monitoring schedule. Overall, the model successfully predicted pesticide concentrations within order-ofmagnitude accuracy. The model outputs predicted the rankings of pesticides with respect to concentrations, which could be utilised to prioritise pesticides that require monitoring among numerous pesticides applied in the river basin.

\section{Acknowledgements}

The authors thank Southern Fukuoka Water Supply Authority for providing the pesticide concentration data and the Chikugo River Office of the Kyusyu Regional Development Bureau of the Ministry of Land, Infrastructure, and Transport for providing the river flow rate data. O. Nagafuchi and T. Inaguma are acknowledged for their assistance in data reduction. This research was partly funded by a Grant-in-Aid for Scientific Research from the Ministry of Health, Labour, and Welfare, Japan (H16-Health-066).

\section{References}

British Crop Protection Council (1994). The Pesticides Manual, 11th Edition, Blackwell, London, UK. British Crop Protection Council (2003). The Pesticides Manual, 13th Edition, Blackwell, London, UK. Census Statistics Office (1997). Census of Agriculture Japan 1995, Association of Agriculture \& Forestry Statistics, Tokyo, Japan.

Census Statistics Office (2002). Census of Agriculture Japan 2000, Association of Agriculture \& Forestry Statistics, Tokyo, Japan.

Dabrowski, J.M., Peall, S.K.C., Niekerk, A.V., Reinecke, A.J., Day, J.A. and Schulz, R. (2002). Predicting runoff-induced pesticide input in agricultural sub-catchment surface waters: linking catchment variables and contamination. Wat. Res., 36(20), 4975-4984.

Dubus, I.G., Brown, C.D. and Beulke, S. (2003). Sources of uncertainty in pesticide fate modeling. Sci. Total Environ., 317, 53-72.

Fukuoka Prefecture (2000). Agriculture \& Forestry of Fukuoka, Fukuoka, Japan.

Geographical Survey Institute (1990). Detailed Digital Information KS-200-1, CD-ROM, Japan Map Center, Tokyo, Japan.

Geographical Survey Institute (1999). Digital Map 50 m Grid (Elevation), CD-ROM, Japan Map Center, Tokyo, Japan.

Inao, K. and Kitamura, Y. (1999). Pesticide paddy field model (PADDY) for predicting pesticide concentrations in water and soil in paddy fields. Pestic. Sci., 55, 38-46.

Japan Plant Protection Association (2000). Pesticide Directory 1999, Tokyo, Japan.

Japan Plant Protection Association (2001). Pesticide Directory 2000, Tokyo, Japan.

Japan Plant Protection Association (2002). Pesticide Directory 2001, Tokyo, Japan.

Japan Plant Protection Association (2003). Pesticide Directory 2002, Tokyo, Japan.

Li, S. and Migita, J. (1992). Pesticide runoff from paddy field and its impact on receiving water. Wat. Sci. Tech., 25(11), 69-76.

Matsui, Y., Itoshiro, S., Buma, B., Hosogoe, K., Yuasa, A., Shinoda, S., Matsushita, T. and Inoue, T. (2002). Predicting pesticide concentrations in river water by hydrologically calibrated basin-scale runoff model. Wat. Sci. Tech., 45(9), 141-148.

Matsui, Y., Inoue, T., Matsushita, T., Yamada, T., Yamamoto, M. and Sumigama, Y. (2005). Effect of uncertainties of agricultural working schedule and Monte-Carlo evaluation of the model input in basinscale runoff model analysis of herbicides. Wat. Sci. Tech., 51(3-4), 329-337.

U.S. Environmental Protection Agency (2004). Estimation Program Interface (EPI) Suite version 3.12, Washington, DC, USA. 